\title{
PENERAPAN PRINSIP PENGUNGKAPAN LENGKAP AKUN PIUTANG PERPAJAKAN PADA LAPORAN KEUANGAN PEMERINTAH PUSAT TA 2017-2019
}

\author{
*Imran Djunur \\ Kementerian Keuangan
}

\section{ARTICLE INFO}

Article History:

Received: 14 September 2020

Accepted: 27 November 2020

Published: 01 December 2020

Keywords:

Government Accounting, LKPP, Full Disclosure Principle, Notes to Financial Statement, Tax Receivable.

\begin{abstract}
In order to be widely used by users of financial statements, information related to tax receivable accounts in LKPP must meet the Full Disclosure Principle relate to assets, liabilities and equity either through faces or Notes to Financial Statements. Complete information will prevent users from misleading and improper decision making or opinions on the financial condition and performance of the central government. This study focuses on the disclosure of information on tax accounts receivable at LKPP because the account has significant value and gets the attention of LKPP users. Through this research, the writer will assess whether the information related to tax receivables in LKPP FY 2017 to 2019 meets the Full Disclosure Principle. To fulfill the principle, LKPP must disclose 9 adequate information related to tax receivable. The results of the analysis show that the disclosure of tax receivables in LKPP FY 2017 and LKPP FY 2018 don't fulfill all the criteria, while LKPP FY 2019 only fulfill 1 criteria. There was no significant increase in the implementation of full disclosure principle of tax receivable within 3 years.
\end{abstract}

\begin{abstract}
ABSTRAK
Agar penyajian nilai piutang pajak dapat dimanfaatkan oleh pengguna laporan keuangan secara luas, informasi terkait akun piutang perpajakan dalam Laporan Keuangan Pemerintah Pusat (LKPP) harus memenuhi Prinsip Pengungkapan Lengkap atas aset, kewajiban dan ekuitas baik melalui face ataupun Catatan atas Laporan Keuangan (CaLK). Informasi yang lengkap akan menghindarkan pengguna laporan keuangan dari hal yang menyesatkan dan pengambilan keputusan atau pendapat yang tidak tepat atas kondisi keuangan dan kinerja pemerintah pusat. Penelitian ini berfokus pada pengungkapan informasi atas akun piutang perpajakan pada LKPP karena akun tersebut memiliki nilai yang signifikan dan mendapat perhatian dari pengguna LKPP. Penelitian ini bertujuan menilai apakah informasi terkait piutang perpajakan pada LKPP TA 2017 s.d 2019 telah memenuhi prinsip pengungkapan lengkap. Hasil analisis menunjukkan bahwa pengungkapan piutang perpajakan pada LKPP TA 2017 dan LKPP TA 2018 belum memenuhi semua kriteria, sedangkan LKPP TA 2019 hanya memenuhi satu kriteria. Tidak ada peningkatan yang berarti dalam prinsip pengungkapan lengkap atas akun piutang perpajakan dalam kurun waktu tiga tahun.
\end{abstract}

How to Cite:

Djunur, Imran. Penerapan Prinsip Pengungkapan Lengkap Akun Piutang Perpajakan pada Laporan Keuangan Pemerintah Pusat TA 2017-2019. Jurnal Ilmiah Wahana Akuntansi, 15(2), 125-152. https:// doi.org/10.21009/wahana.15.022 


\section{PENDAHULUAN}

UU Nomor 17 Tahun 2003 tentang Keuangan Negara mewajibkan Pemerintah menyampaikan laporan pertanggungjawaban atas pelaksanaan Anggaran Pendapatan dan Belanja Negara (APBN) berupa laporan keuangan kepada Dewan Perwakilan Rakyat (DPR) yang selanjutnya disebut sebagai Laporan Keuangan Pemerintah Pusat (LKPP). LKPP memuat kinerja keuangan atas penggunaan anggaran yang ditetapkan dalam APBN. Namun, LKPP tidak hanya ditujukan untuk DPR, melainkan juga kepada pihak lain yaitu kreditur, akademisi, peneliti, investor, dan masyarakat umum, di mana setiap pihak memiliki kepentingan masingmasing dalam memanfaatkan informasi yang disajikan dalam laporan keuangan.

Agar dapat dimanfaatkan oleh berbagai pengguna laporan keuangan, informasi dalam LKPP harus memenuhi karakteristik kualitatif dan prinsip-prinsip yang ditetapkan dalam Standar Akuntansi Pemerintah (SAP), antara lain Prinsip Full Disclosure, yaitu prinsip pengungkapan atau penyajian informasi secara lengkap atas aset, kewajiban dan ekuitas, baik melalui face ataupun CaLK. Pengungkapan informasi dalam LKPP merupakan hal yang penting karena menjadi salah satu dari empat kriteria dalam pemeriksaan BPK terhadap LKPP, selain Kesesuaian dengan SAP, Kepatuhan terhadap peraturan perundang-undangan dan Efektivitas Sistem Pengendalian Intern (Pasal 16 Undang-undang Nomor 15 tahun 2004 tentang Pemeriksaan Pengelolaan dan Tanggung Jawab Keuangan Negara).
Melalui rincian, deskripsi, narasi, tabel, daftar dan grafik, CaLK memandu pengguna LKPP memahami penyajian angka-angka pada Laporan Operasional, Laporan Realisasi Anggaran, Laporan Perubahan SAL, Laporan Perubahan Ekuitas, Laporan Arus Kas dan Neraca. Namun, seringkali bentuk CaLK hanya mengulang informasi, misalnya hanya mengubah tabel menjadi kalimat tanpa memberi informasi tambahan. Bentuk CaLK seperti ini, bukan bentuk CaLK yang diinginkan pengguna LKPP karena tidak menambah informasi bagi mereka. Informasi yang lengkap akan menghindarkan pengguna laporan keuangan dari hal yang menyesatkan dalam pengambilan keputusan atau pendapat atas kondisi keuangan dan kinerja pemerintah pusat. Dalam era internet, diperlukan suatu informasi yang dapat dipahami dan diandalkan untuk meminimalisir berita menyesatkan atau palsu (hoax) terkait kinerja pemerintah pusat, yang jika tidak disediakan dapat menciptakan tuduhan tidak benar (fitnah) terhadap kinerja pemerintah dan mendorong terjadinya kekacauan dalam masyarakat.

Setiap kelompok akun memiliki pengungkapan masing-masing yang harus memenuhi Prinsip Pengungkapan Lengkap. Dalam penelitian ini, penulis membatasi ruang lingkup hanya pada akun Piutang Perpajakan. Akun ini dipilih untuk dianalisis karena mendapat perhatian dari masyarakat, DPR dan Wajib Pajak (WP) dan memiliki persentase yang makin meningkat terhadap total nilai Aset, yaitu $0,99 \%$ (TA 2017), 1,37\% (TA 2018) dan $1,59 \%$ (TA 2019). 
Berdasarkan penjelasan di atas, penelitian ini dilakukan untuk menilai kualitas penerapan prinsip pengungkapan lengkap atas akun piutang perpajakan pada LKPP TA 2017 s.d 2019.

\section{TINJAUAN TEORI}

\section{Penyediaan Informasi Terkait Kinerja}

Keuangan Pemerintah: Akuntabilitas,

\section{Akuntansi dan Laporan Keuangan}

Pemerintah berkewajiban untuk memberikan informasi keuangan yang akan digunakan untuk pengambilan keputusan ekonomi, sosial, dan politik oleh pihak-pihak yang berkepentingan. Laporan keuangan untuk mendukung pembuatan keputusan ekonomi, sosial, dan politik tersebut meliputi informasi yang digunakan untuk (a) membandingkan kinerja keuangan aktual dengan yang dianggarkan, (b) menilai kondisi keuangan dan hasil-hasil operasi, (c) membantu menentukan tingkat kepatuhan terhadap peraturan perundangundangan yang terkait dengan masalah keuangan dan ketentuan lainnya, serta (d) membantu dalam mengevaluasi efisiensi dan efektivitas. Mardiasmo (2018: 203).

Pendapat Mardiasmo tersebut sejalan dengan GASB (Governmental Accounting Standards Board), yang juga menjelaskan pentingnya penyediaan informasi untuk mencapai tujuan tertinggi laporan keuangan, yaitu akuntabilitas. Hal tersebut dicantumkan dalam paragraf 2 Statement No. 34 of the Governmental Accounting Standards, Board Basic Financial Statements - and Management's Discussion and Analysis-for State and Local Governments (June 1999), sebagai berikut:
"Accountability is the paramount objective of governmental financial reporting - the objective from which all other financial reporting objectives flow. Governments' duty to be accountable includes providing financial information that is useful for economic, social, and political decisions. Financial reports that contribute to these decisions include information useful for (a) comparing actual financial results with the legally adopted budget, (b) assessing financial condition and results of operations, (c) assisting in determining compliance with financerelated laws, rules, and regulations, and (d) assisting in evaluating efficiency and effectiveness".

\section{Akuntabilitas tersebut sebenarnya} perwujudan hak dasar masyarakat terhadap pemerintah (Mardiasmo, 2018:214): (1) Hak untuk mengetahui (right to know): mengetahui kebijakan pemerintah, mengetahui keputusan yang diambil pemerintah, dan mengetahui alasan dilakukannya suatu kebijakan dan keputusan tertentu; (2) Hak untuk diberikan informasi (right to be informed): meliputi hak untuk diberi penjelasan secara terbuka atas permasalahan-permasalahan tertentu yang menjadi perdebatan publik; dan (3) Hak untuk didengar aspirasinya (right to be heard and to be listened to)".

Mahmudi (2016:19-20) menjelaskan bahwa akuntabilitas publik yang harus dilakukan oleh organisasi sektor publik terdiri atas beberapa aspek. Dimensi akuntabilitas yang harus dipenuhi oleh lembaga-lembaga publik tersebut antara lain (Hopwood dan Tomkins, 1984; Elwood, 1993) adalah akuntabilitas finansial (financial accountability), yaitu pertanggungjawaban lembaga-lembaga publik untuk menggunakan uang publik (public money) secara ekonomi, 
efisien, dan efektif, tidak ada pemborosan dan kebocoran dana serta korupsi. Akuntabilitas finansial menekankan pada ukuran anggaran dan finansial. Akuntabilitas finansial sangat penting karena pengelolaan keuangan publik menjadi perhatian utama masyarakat. Akuntabilitas finansial mengharuskan lembaga-lembaga publik untuk membuat laporan keuangan untuk menggambarkan kinerja finansial organisasi kepada pihak luar. Akuntansi sektor publik memiliki peran yang sangat penting dalam mendorong terciptanya akuntabilitas finansial. Kekuatan utama akuntansi adalah pada pemberian informasi. Informasi keuangan merupakan produk akuntansi yang sangat powerful untuk mempengaruhi pengambilan keputusan, meskipun informasi keuangan bukanlah satu-satunya informasi yang dibutuhkan untuk mendukung pengambilan keputusan. Informasi keuangan merupakan bahan dasar untuk pengambilan keputusan ekonomi, sosial, dan politik.

Tuntutan terhadap akuntabilitas yang dijelaskan di atas hanya dapat diwujudkan jika ditunjang dengan suatu sistem akuntansi. Sabeni (2008:105) menjelaskan bahwa sistem akuntansi suatu lembaga pemerintahan harus: (a) menunjukkan bahwa semua ketentuan hukum dan perundang-undangan telah dipenuhi, dan (b) menentukan secara wajar dan dengan pengungkapan yang selengkapnya atas posisi keuangan dan hasil operasi dana.

Untuk sektor pemerintahan, sistem akuntansi menggunakan Akuntansi Pemerintahan, yang oleh Bahtiar Arif (2002:3) memiliki tiga tujuan pokok, yaitu:
1. Akuntabilitas (Pertanggungjawaban)

Memberikan informasi keuangan yang lengkap, cermat, dan dalam bentuk dan waktu yang tepat, yang berguna bagi pihak yang bertanggung jawab, terkait kegiatan unit-unit pemerintahan. Fungsi pertanggungjawaban seharusnya menyediakan informasi tentang berbagai tindakan pemerintah selama periode bersangkutan. Jadi, dapat dikatakan bahwa fungsi pertanggungjawaban mengandung arti yang lebih luas dari sekedar ketaatan kepada peraturan. Pertanggungjawaban juga mengharuskan untuk bertindak bijaksana dalam penggunaan sumber-sumber daya yang ada.

\section{Manajerial}

Menyediakan informasi keuangan yang diperlukan untuk perencanaan, penganggaran, pelaksanaan, pemantauan, pengendalian anggaran, perumusan kebijakan, pengambilan keputusan dan penilaian kinerja pemerintah. Tujuan manajerial ini perlu dikembangkan agar organisasi pemerintahan tingkat atas dan menengah dapat mengandalkan informasi keuangan atas pelaksanaan sebelumnya untuk membuat keputusan atau menyusun perencanaan masa yang akan datang.

3. Pengawasan

Memungkinkan terselenggaranya pemeriksaan oleh aparat pengawasan fungsional secara efektif dan efisien.

Kedudukan akuntansi pemerintahan tersebut bertujuan menyajikan informasi 
ekonomi dari suatu entitas ekonomi. Informasi ekonomi yang dihasilkan oleh akuntansi tersebut berguna bagi pihak-pihak yang ada dalam entitas ekonomi tersebut maupun pihak-pihak di luar entitas tersebut. Dalam akuntansi pemerintahan, informasi yang disajikan dalam laporan keuangan bertujuan umum untuk memenuhi kebutuhan informasi dari semua kelompok pengguna. Dengan demikian, laporan keuangan tidak dirancang untuk memenuhi kebutuhan spesifik dari masing-masing kelompok pengguna. Meskipun memiliki akses terhadap detail informasi yang tercantum di dalam laporan keuangan, pemerintah wajib memperhatikan informasi yang disajikan dalam laporan keuangan untuk keperluan perencanaan, pengendalian dan pengambilan keputusan. Selanjutnya pemerintah dapat menentukan bentuk dan jenis informasi tambahan untuk kebutuhan sendiri di luar jenis informasi yang diatur dalam kerangka konseptual ini maupun standar-standar akuntansi yang dinyatakan lebih lanjut. (Rachmat, 2011:51).

Output akhir dari Akuntansi Pemerintahan adalah laporan keuangan pemerintahan yang ditujukan untuk berbagai macam pengguna laporan keuangan. Mardiasmo (2018:215) menjelaskan bahwa setiap pemakai laporan keuangan pemerintah memiliki kebutuhan dan kepentingan yang berbeda-beda terhadap informasi keuangan yang diberikan oleh pemerintah. Bahkan di antara kelompok pemakai laporan keuangan akan timbul konflik kepentingan. Laporan keuangan pemerintah disediakan untuk memberi informasi kepada berbagai kelompok pemakai (general purposive). Laporan keuangan pemerintah merupakan hak publik yang harus diberikan oleh pemerintah, baik pusat maupun daerah. Hak publik atas informasi keuangan muncul sebagai konsekuensi konsep pertanggungjawaban publik, yaitu konsep yang mensyaratkan organisasi publik untuk memberikan laporan keuangan sebagai bukti pertanggungjawaban dan pengelolaan (accountability \& stewardship).

Dengan demikian, substansi dan unsur utama dari akuntabilitas, sistem akuntansi dan laporan keuangan adalah pengungkapan informasi kepada berbagai macam pihak yang membutuhkan. Sujarweni memperingatkan bahwa jika laporan keuangan organisasi sektor publik buruk maka akan menyebabkan: (1) Kepercayaan masyarakat kepada pengelola dana publik (pemerintah) akan menurun; (2) Penanam modal atau investor tidak berani menanamkan modalnya lagi; (3) Para donatur atau penyumbang dana akan mengurangi atau menghentikan bantuannya; (4) Laporan keuangan tidak dapat digunakan untuk pengambilan keputusan dan pengukuran kinerja; dan (5) Laporan keuangan tidak dapat diaudit.

\section{Prinsip Pengungkapan Lengkap}

Untuk memenuhi kebutuhan informasi pengguna laporan keuangan, pelaporan keuangan secara umum harus mengikuti suatu kerangka konseptual, yang dalam bidang akuntansi pemerintahan diatur oleh Peraturan Pemerintah Nomor 71 Tahun 2010 tentang Standar Akuntansi Pemerintahan (PP 71). Kerangka Konseptual adalah konsep yang 
mendasari penyusunan dan pengembangan Standar Akuntansi Pemerintahan (SAP). Tujuannya adalah sebagai acuan bagi: (1) penyusun standar dalam melaksanakan tugasnya; (2) penyusun laporan keuangan dalam menanggulangi masalah akuntansi yang belum diatur dalam standar; (3) Auditor dalam memberikan pendapat mengenai apakah laporan keuangan disusun sesuai dengan standar; dan (4) para pengguna laporan keuangan dalam menafsirkan informasi yang disajikan pada laporan keuangan yang disusun sesuai dengan standar (Lampiran I.01 PP 71).

Prinsip pengungkapan lengkap adalah satu dari delapan prinsip akuntansi dan pelaporan keuangan yang diyatakan dalam PP 71 harus dipenuhi oleh Pemerintah. Prinsip ini mensyaratkan LKPP menyajikan secara lengkap informasi yang dibutuhkan oleh pengguna. Tentu saja, informasi tersebut harus memenuhi karakteristik kualitatif laporan keuangan, yaitu relevan, andal, dapat dibandingkan dan dapat dipahami untuk memenuhi tujuan pelaporan keuangan.

Jenis pengungkapan informasi dalam laporan keuangan dapat dijelaskan sebagai berikut:

1. Menurut Tingkat Urgensinya

Menurut Naim dan Rahman (2000), pengungkapan dalam laporan keuangan dapat dikelompokkan menjadi dua yaitu pengungkapan wajib (mandatory disclosure) dan pengungkapan sukarela (voluntary disclosure) ( $\mathrm{Na}^{\prime} \mathrm{im}$ dan Rakhman, 2000). Dalam kualitas informasi keuangan terdapat dua jenis pengungkapan (disclosure) yang diterbitkan oleh perusahaan. Pengungkapan tersebut adalah pengungkapan wajib (mandatory disclosure) merupakan pengungkapan yang diwajibkan peraturan pemerintah dan pengungkapan sukarela (voluntary disclosure) merupakan pengungkapan yang tidak diwajibkan peraturan. Penelitian tentang pencapaian efisiensi dan sebagai sarana akuntabilitas publik, pengungkapan laporan keuangan menjadi faktor yang signifikan (dikutip dalam Eko Susilo Haryadi, dkk, 2015:185).

2. Menurut Tingkat Keluasan Pengungkapan Ada tiga konsep mengenai luas pengungkapan laporan keuangan yaitu adequate, fair, dan full disclosure. Konsep yang paling sering digunakan adalah adequate disclosure (pengungkapan cukup), yaitu pengungkapan minim yang disyaratkan oleh peraturan yang berlaku dimana pada tingkat ini investor dapat menginterpretasikan angka-angka dalam laporan keuangan. Konsep fair disclosure (pengungkapan wajar) mengandung sasaran etis dengan menyediakan informasi yang layak terhadap investor potensial. Sedangkan full disclosure (pengungkapan penuh) memiliki kesan penyajian laporan keuangan yang berlebihan sehingga banyak pihak berpendapat bahwa full disclosure merupakan konsep yang dapat merugikan perusahaan (Eko Susilo Haryadi, dkk, 2015:185). 


\section{Catatan atas Laporan Keuangan}

PSAP 04 tentang Catatan atas Laporan Keuangan mensyaratkan CaLK harus disajikan secara sistematis dan meliputi penjelasan atau daftar terinci atau analisis atas nilai suatu pos yang disajikan dalam Laporan Realisasi Anggaran (LRA), Laporan Perubahan Saldo Anggaran Lebih (LP SAL), Neraca, Laporan Operasional (LO), Laporan Arus Kas (LAK), dan Laporan Perubahan Ekuitas (LPE). Termasuk pula dalam CaLK adalah penyajian informasi yang diharuskan dan dianjurkan oleh PSAP serta pengungkapan-pengungkapan lainnya yang diperlukan untuk penyajian yang wajar atas laporan keuangan, seperti kewajiban kontingensi dan komitmen-komitmen lainnya.

Secara umum, dalam rangka pengungkapan yang lengkap dan memadai, CaLK mengungkapkan hal-hal sebagai berikut: (1) Informasi Umum tentang Entitas Pelaporan dan Entitas Akuntansi; (2) Informasi tentang kebijakan fiskal/keuangan dan ekonomi makro; (3) Ikhtisar pencapaian target keuangan selama tahun pelaporan berikut kendala dan hambatan yang dihadapi dalam pencapaian target; (4) Informasi tentang dasar penyajian laporan keuangan dan kebijakan akuntansi yang dipilih untuk diterapkan atas transaksi-transaksi dan kejadian-kejadian penting lainnya; (5) Rincian dan penjelasan masing-masing pos yang disajikan pada lembar muka laporan keuangan; (6) Informasi yang diharuskan oleh PSAP yang belum disajikan dalam lembar muka laporan keuangan; dan (7) Informasi lainnya yang diperlukan untuk penyajian yang wajar, yang tidak disajikan dalam lembar muka laporan keuangan.

CaLK harus menyajikan informasi yang diharuskan dan dianjurkan oleh PSAP lainnya serta pengungkapan-pengungkapan lain yang diperlukan untuk penyajian wajar atas laporan keuangan, seperti kewajiban kontingensi dan komitmen-komitmen lain. Pengungkapan informasi dalam CaLK harus dapat memberikan informasi lain yang belum disajikan dalam bagian lain laporan keuangan.

Pengungkapan informasi dalam CaLK harus menyajikan informasi yang tidak mengulang rincian (misalnya rincian persediaan, rincian aset tetap, atau rincian pengeluaran belanja) dari seperti yang telah ditampilkan pada lembar muka laporan keuangan. Dalam beberapa kasus, pengungkapan kebijakan akuntansi, untuk dapat meningkatkan pemahaman pembaca, harus merujuk ke rincian yang disajikan pada tempat lain di laporan keuangan. Dalam kebijakan akuntansi pos aset tetap disebutkan dasar pengukuran adalah harga perolehan. Penelitian terhadap akun-akun yang mendukung pos aset tersebut menunjukkan ada salah satu akun aset dengan harga selain harga perolehan, karena aset dimaksud diperoleh dari donasi.

CaLK juga harus mengungkapkan informasi yang bila tidak diungkapkan akan menyesatkan bagi pembaca laporan, misalnya kejadian penting selama tahun pelaporan, seperti: (1) Penggantian manajemen pemerintahan selama tahun berjalan; (2) Kesalahan manajemen terdahulu yang telah dikoreksi oleh manajemen baru; (3) Komitmen 
atau kontingensi yang tidak dapat disajikan pada Neraca; (4) Penggabungan atau pemekaran entitas tahun berjalan; dan (5) Kejadian yang mempunyai dampak sosial, misalnya adanya pemogokan yang harus ditanggulangi pemerintah.

\section{Prinsip Pengungkapan Lengkap atas Piutang Perpajakan}

Piutang pajak adalah piutang yang timbul atas pendapatan pajak sebagaimana diatur dalam undang-undang perpajakan, yang belum dilunasi sampai dengan akhir periode laporan keuangan (Mursyidi, 2013:133). Sebagai akun yang signifikan, piutang pajak harus diungkapkan secara lengkap dalam laporan keuangan.

Menurut Martani, dkk (2012: 229-234), pengungkapan tersebut terbagi dalam tiga bagian, yaitu: Pengungkapan Kebijakan Akuntansi, Pengungkapan rincian piutang yang menjelaskan angka dalam laporan keuangan pokok, serta penjelasan lain yang material dan signifikan. Pengungkapan kebijakan akuntansi piutang diletakkan bersamaan dengan pengungkapan instrumen keuangan. Kebijakan akuntansi yang dijelaskan dalam kebijakan akuntansi piutang di antaranya adalah: (1) metode pengakuan awal; (2) metode pengukuran setelah perolehan; (3) metode untuk menghitung penurunan nilai; dan (4) penjelasan mengenai penghapusan piutang.

Catatan atas Laporan Keuangan dalam rincian laporan keuangan dan penjelasan penting tentang piutang, meliputi: (1) jenis piutang yang dimiliki, misalnya menurut mata uang dan sifat piutang; (2) rincian piutang yang dilakukan kepada pelanggan dengan jumlah signifikan; (3) identifikasi piutang yang diklasifikasikan sebagai aset lancar dan aset tidak lancar; (4) penurunan nilai piutang dan penjelasan penurunan nilai yang dilakukan secara kolektif maupun individu; (5) piutang yang digunakan sebagai jaminan; (6) informasi terkait risiko, yang menjelaskan piutang yang telah jatuh tempo atau mengalami penurunan nilai, nilai terbawa dari piutang yang mengalami penurunan nilai yang telah dinegosiasikan dan analisis umur piutang atas piutang yang telah jatuh tempo; (7) Nilai wajar piutang; dan (8) semua konsentrasi risiko kredit atas piutang.

Piutang disajikan dalam laporan posisi keuangan sebesar nilai diamortisasi dikurangi kerugian penurunan nilai. Catatan atas Laporan Keuangan menjelaskan kebijakan akuntansi, rincian piutang menurut jenis, rekonsiliasi cadangan piutang, dan informasi khusus terkait piutang seperti piutang dijaminkan dan penjelasan rinci debitur tertentu.

Kieso dan Weigandt (2008:367), menyebutkan aturan umum dalam pengklasifikasian piutang adalah:

Memisahkan berbagai jenis piutang yang dimiliki perusahaan, jika material; Menjamin bahwa akun penilaian secara tepat mengoffset akun piutang yang terkait; (3) Menentukan bahwa piutang yang diklasifikasikan dalam kelompok aset lancar akan dikonversikan menjadi kas dalam satu tahun atau satu siklus operasi tergantung mana yang lebih panjang; (4) Mengungkapkan setiap kontingensi kerugian yang ada pada piutang; (5) Mengungkapkan setiap piutang yang digadaikan sebagai jaminan; dan 
mengungkapkan semua konsentrasi yang signifikan dari risiko kredit yang berasal dari piutang.

Selanjutnya Kieso dan Weigandt (2008:367) menjelaskan bahwa terdapat konsentrasi risiko kredit apabila piutang memiliki karakteristik serupa yang bisa mempengaruhi daya-tagihnya. Karakteristik-karakteristik umum ini mungkin berupa perusahaan-perusahaan debitur yang berada dalam industri yang sama atau wilayah negara yang sama. Sebagai contoh, Quantum Corporation melaporkan bahwa penjualan disk drive kepada lima pelanggan utamanya (termasuk Hawlett-Packard) mewakili 40 persen pendapatannya pada tahun 2003 .

Pemakai laporan keuangan ingin mengetahui apakah sebagian besar piutang dari penjualan tersebut merupakan transaksi dengan pelanggan yang menghadapi ketidakpastian kondisi ekonomi. Tidak ada pedoman numerik yang disediakan menyangkut apa yang dimaksud dengan "konsentrasi risiko kredit". Tiga hal yang harus diungkapkan dengan konsentrasi yang teridentifikasi, yaitu (1) Informasi mengenai karakteristik yang memunculkan konsentrasi; (2) Jumlah kerugian yang bisa dialami seandainya tidak bisa membayar, dan (3) Informasi menyangkut setiap jaminan yang berhubungan dengan piutang.

Untuk LKPP, pengungkapan piutang pajak diatur dalam Buletin Teknis Standar Akuntansi Pemerintahan Nomor 16 tentang Akuntansi Piutang Berbasis Akrual (Bultek Nomor 16) yang menjelaskan bahwa piutang disajikan dan diungkapkan secara memadai atau cukup dalam CaLK. Informasi dimaksud dapat berupa: (1)
Kebijakan akuntansi yang digunakan dalam pengakuan, penilaian dan pengukuran piutang; (2) Rincian jenis-jenis, saldo menurut umur untuk mengetahui tingkat kolektibilitasnya; (3) Penjelasan atas penyelesaian piutang, masih di Kementerian Negara/Lembaga/Pemda atau sudah diserahkan penagihannya kepada PUPN; (4) Jaminan atau sita jaminan jika ada; dan (5) Penghentian pengakuan piutang (daluarsa, hapus buku, ekstrakomptabel dan hapus tagih).

LKPP tersebut disusun secara berjenjang dari laporan keuangan tingkat satuan kerja hingga tingkat pusat sehingga kewajiban pengungkapan informasi piutang perpajakan dalam Bultek Nomor 16 kemudian dikuatkan lagi dan dirinci dengan peraturan di bawah Peraturan Pemerintah, yaitu:

1. Peraturan Menteri Keuangan Nomor 43/ PMK.03/2018 tentang Kebijakan Akuntansi Penghapusbukuan Piutang Pajak yang Telah Daluwarsa.

Informasi yang wajib diungkapkan adalah: (a) Piutang pajak yang telah daluwarsa; (b) Piutang pajak yang telah dihapusbukukan; (c) Piutang ekstrakomptabel; dan (d) Piutang pajak yang telah dihapustagihkan.

2. Peraturan Direktur Jenderal (Dirjen) Pajak Nomor 08/PJ/2009 tentang Pedoman Akuntansi Piutang Pajak. Informasi yang wajib diungkapkan adalah: (a) Kebijakan akuntansi yang digunakan dalam penilaian, pengakuan dan pengukuran piutang; (b) Rincian Saldo Piutang Pajak berdasarkan jenis pajak dan berdasarkan umur piutang 
untuk mengetahui tingkat kolektibilitasnya;

(c) Penjelasan atas penyelesaian piutang (tindakan penagihan); (d) Jenis jaminan atau sita jaminan jika ada; dan (e) Informasi tentang terjadinya perselisihan (sengketa) piutang pajak.

Peraturan ini sudah diganti dengan Peraturan Dirjen Pajak Nomor Per-20/ $\mathrm{PJ} / 2020$ tentang Pedoman Akuntansi Piutang Pajak. Terdapat tambahan informasi yang harus diungkapkan yaitu piutang pajak yang telah dilakukan penghapustagihan dan informasi lain yang dianggap penting mengenai piutang pajak.

3. Peraturan Dirjen Bea dan Cukai Nomor P47/BC/2010 tentang Pedoman Penatausahaan Piutang di Direktorat Jenderal Bea dan Cukai (DJBC).

Informasi yang wajib diungkapkan adalah: (a) Kebijakan akuntansi yang digunakan dalam penilaian, pengakuan dan pengukuran piutang yaitu dasar pengakuan timbulnya masing-masing piutang, dasar yang dijadikan nilai piutang, penyisihan, pelimpahan piutang, pelimpahan penagihan dan penghapusan; (b) Rincian saldo piutang berdasarkan jenis pajak, status penagihan, jenis dokumen sumber piutang, status importir/ pengusaha (aktif/blokir/ tidak aktif), umur piutang dan kualitas piutang untuk mengetahui tingkat kolektibilitasnya; (c) Penjelasan atas penyelesaian piutang (tindakan penagihan) atau sudah diserahkan penagihannya kepada Kantor Pelayanan Kekayaan Negara dan Lelang (KPKNL); (d) Jenis jaminan atau sita jaminan jika ada; (e) Informasi tentang terjadinya perselisihan (sengketa) piutang seperti piutang dengan nilai signifikan yang masih dalam proses banding sampai dengan periode pelaporan; dan (f) Penyisihan piutang tidak tertagih.

Penyediaan informasi piutang perpajakan yang telah disebutkan di atas, antara lain, ditujukan untuk pengukuran kinerja terkait pengelolaan pajak, sebagaimana diungkapkan Mardiasmo (2018:19) bahwa untuk melakukan pengukuran kinerja, pemerintah memerlukan informasi akuntansi terutama untuk menentukan indikator kinerja (performance indicator) sebagai dasar penilaian kinerja. Manajemen akan kesulitan untuk melakukan pengukuran kinerja apabila tidak ada indikator kinerja yang memadai. Indikator kinerja tersebut dapat bersifat finansial maupun non finansial. Informasi akuntansi memiliki peran utama dalam menentukan indikator kinerja sektor publik.

\section{METODE PENELITIAN \\ Pengumpulan Data}

Informasi piutang perpajakan diperoleh melalui proses identifikasi terhadap CALK LKPP TA 2017 s.d 2019.

\section{Variabel Penelitian}

Untuk menilai apakah penerapan prinsip pengungkapan lengkap (full disclosure) atas akun perpajakan telah memadai, penulis menggunakan variabel penelitian berupa kriteria atas kelengkapan pengungkapan akun 
akun perpajakan yang bersumber dari Bultek Nomor 16, peraturan, dan literatur akuntansi, sebagai berikut:

Kriteria 1: Pengungkapan Kebijakan Akuntansi Terkait Piutang Perpajakan

Kebijakan akuntansi adalah prinsip-prinsip, dasar -dasar, konvensi-konvensi, aturan-aturan, dan praktik-praktik spesifik yang dipilih oleh suatu entitas pelaporan dalam penyusunan dan penyajian laporan keuangan. Kebijakan akuntansi mencakup pengakuan, pengukuran dan pengungkapan suatu akun.

\section{Kriteria 2: Pengungkapan Piutang Pajak} Menurut Umur untuk Mengetahui Tingkat

\section{Kolektibilitasnya}

Tingkat kolektibilitas adalah tingkat ketertagihan piutang pajak yang diukur berdasarkan kepatuhan membayar kewajiban oleh Penanggung Pajak. Makin lama Penanggung Pajak menunda pembayaran, makin sulit pemerintah mencairkan piutang pajak.

\section{Kriteria 3: Pengungkapan Penyelesaian Piutang Pajak}

Penyelesaian piutang adalah tahapan tindakan penagihan yang dilakukan oleh pemerintah untuk menagih pembayaran tunggakan dari WP. Tindakan penagihan Pajak adalah serangkaian tindakan agar Penanggung Pajak melunasi utang pajak dan biaya penagihan pajak dengan menegur atau mengingatkan, melaksanakan penagihan seketika dan sekaligus, memberitahukan Surat Paksa (SP), mengusulkan pencegahan, melaksanakan penyitaan, melaksanakan penyanderaan, dan menjual barang yang telah disita.

Kriteria 4: Pengungkapan Jaminan atau Sita

\section{Jaminan}

Jaminan atau agunan adalah barang yang diserahkan oleh WP sebagai jaminan dalam rangka permohonan angsuran atau penundaan pembayaran utang pajak sesuai dengan ketentuan peraturan perundang-undangan perpajakan. Sita jaminan atau barang sitaan adalah barang Penanggung Pajak yang dijadikan jaminan piutang pajak sesuai dengan hasil penyitaan yang dilakukan oleh Jurusita Pajak.

\section{Kriteria 5: Pengungkapan Penyelesaian} Piutang atau Tindakan Penagihan Pajak

Sengketa pajak adalah sengketa yang timbul dalam bidang perpajakan antara WP atau penanggung Pajak dengan pejabat yang berwenang sebagai akibat dikeluarkannya keputusan yang dapat diajukan Banding atau Gugatan kepada Pengadilan Pajak berdasarkan peraturan perundang-undangan perpajakan, termasuk Gugatan atas pelaksanaan penagihan berdasarkan Undang-undang Penagihan Pajak dengan SP. Upaya Hukum yang dapat ditempuh oleh WP adalah keberatan, banding, gugatan dan peninjauan kembali.

\section{Kriteria 6: Pengungkapan Piutang Pajak yang Telah Daluwarsa}

Hak untuk melakukan penagihan pajak menjadi daluwarsa setelah: (a) Piutang perpajakan di Direktorat Jenderal Pajak (DJP): melampaui waktu lima tahun terhitung sejak penerbitan STP, SKPKB, SKPKBT, dan Surat Keputusan (SK) Pembetulan, SK Keberatan, Putusan Banding, serta Putusan Peninjauan Kembali. Daluwarsa penagihan pajak tertangguh apabila diterbitkan SP, ada pengakuan utang pajak dari 
WP baik langsung maupun tidak langsung atau dilakukan penyidikan tindak pidana di bidang perpajakan; dan (b) Piutang perpajakan di BC: melampaui waktu sepuluh tahun sejak timbulnya kewajiban membayar.

\section{Kriteria 7: Pengungkapan Penghapusbukuan Piutang}

Penghapusbukuan adalah pernyataan keputusasaan tentang penagihan suatu piutang, dapat diawali/diiringi suatu pengumuman yuridis -formil tentang suatu pembebasan piutang kepada pihak tertentu, sebagian atau seluruhnya, disertai alasan dan latar belakang keputusan.

\section{Kriteria 8: Pengungkapan Piutang Pajak Ekstrakomptabel}

Piutang ekstrakomptabel adalah piutang yang dihapusbukukan dari neraca berdasarkan alasanalasan tersebut di atas dan kemudian dicatat di luar Neraca. Daftar piutang pajak ekstrakomptabel adalah kelanjutan dari penghapusan piutang pajak sehingga harus juga memuat informasi yang sama seperti pengungkapan penghapusan piutang pajak, yaitu jenis piutang, nama debitur, nilai piutang, nomor dan tanggal keputusan penghapusbukuan piutang, dan penjelasan lainnya yang dianggap perlu.

\section{Kriteria 9: Pengungkapan Penghapustagihan Piutang Pajak}

Penghapustagihan adalah penghapusan Piutang Negara setelah Penghapusbukuan dilakukan dengan menghapuskan hak tagih Negara. Penghapustagihan piutang pajak adalah kelanjutan dari penghapusbukuan piutang pajak dan pencatatan secara ekstrakomptabel sehingga harus pengungkapan penghapustagihan piutang pajak harus juga memuat informasi yang sama, yaitu jenis piutang, nama debitur, nilai piutang, nomor dan tanggal keputusan penghapusbukuan piutang, dan penjelasan lainnya yang dianggap perlu.

\section{Metode Analisis Data}

Metode analisis yang digunakan dalam penelitian ini adalah analisis deskriptif. Penelitian dimulai dengan mendeskripsikan bentuk informasi piutang pajak yang diungkapkan dalam LKPP TA 2017 s.d 2019, kemudian melakukan analisis kesesuaian antara bentuk pengungkapan dengan kriteria pemenuhan Prinsip Pengungkapan Lengkap.

\section{HASIL \\ PENELITIAN \\ DAN \\ PEMBAHASAN}

\section{Penilaian Tingkat Penerapan Prinsip}

\section{Pengungkapan Lengkap}

Berdasarkan analisis terhadap bentuk pengungkapan informasi akun piutang perpajakan dengan menggunakan sembilan kriteria yang telah dijelaskan sebelumnya, diperoleh hasil sebagai berikut:

\section{Kriteria 1: Pengungkapan Kebijakan} Akuntansi Terkait Piutang Perpajakan

Kebijakan akuntansi adalah prinsipprinsip, dasar-dasar, konvensi-konvensi, aturan-aturan, dan praktik-praktik spesifik yang dipilih oleh suatu entitas pelaporan dalam penyusunan dan penyajian laporan keuangan (Paragraf 8 PSAP Nomor 1 Penyajian Laporan Keuangan).

Hasil analisis untuk kriteria 1 ini disajikan pada Tabel 1 di bawah ini. 
Tabel 1

Pengungkapan Kebijakan Akuntansi

\begin{tabular}{cll}
\hline LKPP & & \multicolumn{1}{c}{ URAIAN } \\
\hline 2017 & Bentuk & Halaman 115: Piutang Perpajakan yang diakui pada \\
& Pengungkapan & SKPKB/SKPKBT adalah sebesar nilai yang disetujui oleh WP \\
& & untuk Tahun Pajak 2008 dan seterusnya. Hal ini tidak berlaku \\
& pada STP dan SPPT karena pada jenis ketetapan tersebut tidak \\
& ada unsur nilai setuju atau tidak setuju atas nilai ketetapan \\
& pajak. Piutang Perpajakan pada DJBC merupakan tagihan \\
& pajak yang telah mempunyai surat ketetapan yang dapat \\
& dijadikan kas dan belum diselesaikan pada tanggal neraca yang \\
& diharapkan dapat diterima dalam jangka waktu tidak lebih dari \\
& satu tahun.
\end{tabular}

Hasil Penilaian Pengungkapan belum memadai karena kebijakan akuntansi terkait penambah dan pengurang piutang pajak tidak diungkapkan serta penyisihan piutang pajak.

$\begin{array}{lll}\text { Bentuk } & \text { Halaman 127: Piutang Perpajakan yang diakui pada } \\ & \text { Pengungkapan } & \text { SKPKB/SKPKBT adalah sebesar nilai yang disetujui oleh WP } \\ & \text { untuk Tahun Pajak 2008 dan seterusnya. Hal ini tidak berlaku } \\ & \text { pada STP dan SPPT karena pada jenis ketetapan tersebut tidak } \\ & \text { ada unsur nilai setuju atau tidak setuju atas nilai ketetapan } \\ & \text { pajak. Piutang Perpajakan pada DJBC merupakan tagihan } \\ & \text { pajak yang telah mempunyai surat ketetapan yang dapat } \\ & \text { dijadikan kas dan belum diselesaikan pada tanggal neraca yang } \\ & \text { diharapkan dapat diterima dalam jangka waktu tidak lebih dari } \\ & \text { satu tahun. }\end{array}$

Hasil Penilaian Pengungkapan belum memadai karena kebijakan akuntansi terkait penambah dan pengurang piutang pajak tidak diungkapkan serta penyisihan piutang pajak.

\begin{tabular}{lll}
\hline 2019 & Bentuk & Halaman 143: \\
Pengungkapan & Piutang Perpajakan pada DJP merupakan tagihan pajak yang \\
& tercantum dalam SKPKB/SKPKBT, dan STP atau SPPT yang \\
& belum dilunasi s.d 31 Desember 2019. Piutang Perpajakan pada \\
& DJBC merupakan tagihan pajak yang telah mempunyai surat \\
& ketetapan yang dapat dijadikan kas dan belum diselesaikan \\
& pada tanggal neraca yang diharapkan dapat diterima dalam \\
& jangka waktu tidak lebih dari satu tahun. \\
& Pengungkapan belum memadai karena kebijakan akuntansi \\
& terkait penambah dan pengurang piutang pajak tidak \\
Hasil Penilaian & diungkapkan serta penyisihan piutang pajak.
\end{tabular}

Sumber: Data diolah oleh peneliti, Tahun 2020 
Bagian kebijakan akuntansi pada CaLK menjelaskan hal-hal berikut ini: (a) dasar pengukuran yang digunakan dalam penyusunan laporan keuangan; (b) sampai sejauh mana kebijakan-kebijakan akuntansi yang berkaitan dengan ketentuan-ketentuan masa transisi Pemerintahan diterapkan oleh suatu entitas pelaporan; dan (c) setiap kebijakan akuntansi tertentu yang diperlukan untuk memahami laporan keuangan (Paragraf 108 PSAP Nomor 1 Penyajian Laporan Keuangan).

Pengguna laporan keuangan perlu mengetahui basis-basis pengukuran yang digunakan sebagai landasan dalam penyajian laporan keuangan. Apabila lebih dari satu basis pengukuran digunakan dalam penyusunan laporan keuangan, maka informasi yang disajikan harus cukup memadai untuk dapat mengindikasikan aset dan kewajiban yang menggunakan basis pengukuran tersebut (Paragraf 109 PSAP Nomor 1 Penyajian Laporan Keuangan). Kebijakan akuntansi yang dijelaskan dalam kebijakan akuntansi piutang di antaranya adalah metode pengakuan awal, dan metode pengukuran setelah perolehan (Martani dkk:2012).

Berdasarkan referensi tersebut, informasi tentang kebijakan akuntansi yang penting namun belum diungkapkan dalam LKPP TA 2017 s.d 2019 adalah: (a) Metode pengukuran piutang pajak, yaitu nilai yang digunakan sebagai dasar pencatatan pertama kali, penambahan dan pengurangan piutang pajak; dan (b) Metode pengukuran penyisihan piutang pajak, yaitu nilai agunan dan persentase yang digunakan untuk menghitung nilai penyisihan piutang pajak.

Ketidaklengkapan pengungkapan kebijakan akuntansi menyebabkan pengguna LKPP tidak dapat: (a) Mengetahui apakah kebijakan akuntansi masih sama atau berbeda dengan tahuntahun sebelumnya. Konsistensi penggunaan kebijakan akuntansi akan membuat LKPP TA 2017 s.d 2019 dapat dibandingkan dengan LKPP tahun-tahun sebelumnya, sebagaimana yang diprasyaratkan dalam karakteristik kualitatif laporan keuangan, yaitu suatu informasi harus dapat dibandingkan untuk mewujudkan tujuan laporan keuangan. Jika ada perubahan kebijakan akuntansi, pengguna laporan keuangan dapat menilai apakah kebijakan akuntansi tahun ini membuat LKPP TA 2017 s.d 2019 lebih sesuai atau tidak dengan kondisi keuangan negara; (b) Membuat penilaian, keputusan keuangan dan keperluan lain secara andal, terutama terkait strategi penagihan piutang pajak yang akan ditempuh tahun-tahun selanjutnya; dan (c) Memahami isi LKPP secara lebih baik, terutama penyajian angka terkait akun piutang perpajakan.

2. Kriteria 2: Pengungkapan Piutang Pajak Menurut Umur dan Tingkat Kolektibilitas

Hasil analisis untuk kriteria 2 ini disajikan pada Tabel 2. 
Tabel 2

Pengungkapan Pajak Menurut Umur dan Tingkat Kolektibilitas

\begin{tabular}{|c|c|c|c|c|}
\hline LKPP & \multicolumn{4}{|c|}{ URAIAN } \\
\hline \multirow[t]{9}{*}{2017} & \multirow{8}{*}{$\begin{array}{l}\text { Bentuk } \\
\text { Pengungkapan }\end{array}$} & \multicolumn{3}{|c|}{ Lampiran 8B piutang pajak menurut umur dalam miliar rupiah: } \\
\hline & & Kelompok & DJP & \multirow{7}{*}{$\begin{array}{r}\text { DJBC } \\
1.306 \\
511 \\
32 \\
3.337\end{array}$} \\
\hline & & $\leq 1$ tahun & 17.399 & \\
\hline & & $\overline{1}$ s.d $\leq 2$ tahun & 8.270 & \\
\hline & & 2 s.d $\leq 3$ tahun & 6.197 & \\
\hline & & 3 s.d $\leq 4$ tahun & 3.855 & \\
\hline & & 4 s.d $\leq 5$ tahun & 5.977 & \\
\hline & & $>5$ tahun & 11.734 & \\
\hline & Hasil Penilaian & \multicolumn{3}{|c|}{$\begin{array}{l}\text { Pengungkapan belum memadai karena piutang pajak di DJP hanya } \\
\text { disajikan menurut umur, belum disajikan menurut tingkat kolektibilitasnya, } \\
\text { yaitu lancar, kurang lancar, diragukan, dan macet. }\end{array}$} \\
\hline \multirow[t]{9}{*}{2018} & Bentuk & \multicolumn{3}{|c|}{ Lampiran 8B piutang pajak menurut umur dalam miliar rupiah: } \\
\hline & Pengungkapan & Kelompok Umur & DJP & DJBC \\
\hline & & $\leq 1$ tahun & 20.034 & 9.981 \\
\hline & & 1 s.d $\leq 2$ tahun & 13.692 & 67 \\
\hline & & 2 s.d $\leq 3$ tahun & 9.816 & 21 \\
\hline & & 3 s.d $\leq 4$ tahun & 7.219 & 3.316 \\
\hline & & 4 s.d $\leq 5$ tahun & 4.698 & \\
\hline & & $>5$ tahun & 12.628 & \\
\hline & Hasil Penilaian & \multicolumn{3}{|c|}{$\begin{array}{l}\text { Pengungkapan belum memadai karena piutang pajak di DJP hanya } \\
\text { disajikan menurut umur, belum disajikan menurut tingkat kolektibilitasnya, } \\
\text { yaitu lancar, kurang lancar, diragukan, dan macet. }\end{array}$} \\
\hline \multirow[t]{16}{*}{2019} & Bentuk & \multicolumn{3}{|c|}{ Lampiran 8B piutang pajak menurut umur dalam miliar rupiah: } \\
\hline & Pengungkapan & Kelompok Umur & DJP & DJBC \\
\hline & & $\leq 1$ tahun & $\overline{21.2} 47$ & 18.649 \\
\hline & & 1 s.d $\leq 2$ tahun & 12.780 & \\
\hline & & 2 s.d $\leq 3$ tahun & 12.798 & 73 \\
\hline & & 3 s.d $<4$ tahun & 8.610 & 3.307 \\
\hline & & 4 s.d $\leq 5$ tahun & 6.671 & \\
\hline & & $>5$ tahun & 10.521 & \\
\hline & & \multicolumn{3}{|c|}{ Halaman 284, piutang pajak menurut tingkat kolektibilitas: } \\
\hline & & Kolektibilitas & Bruto Pi & tang \\
\hline & & Lancar & & 8.088 \\
\hline & & Kurang Lancar & & 11.269 \\
\hline & & Diragukan & & 18.844 \\
\hline & & Macet & & 34.428 \\
\hline & & Jumlah & & 72.630 \\
\hline & Hasil Penilaian & \multicolumn{3}{|c|}{$\begin{array}{l}\text { Pengungkapan memadai karena piutang sudah disajikan menurut tingkat } \\
\text { kolektibilitas. }\end{array}$} \\
\hline
\end{tabular}

Sumber: Data diolah oleh peneliti, Tahun 2020

Untuk LKPP TA 2017 dan 2018, pengungkapan belum memadai karena tingkat kolektibilitas piutang perpajakan di DJP tidak hanya ditentukan oleh umur piutang tetapi juga ditentukan oleh kriteria lain sebagaimana diatur dalam Peraturan Dirjen Pajak Nomor: PER-02/PJ/2012 tentang Penggolongan Kualitas Piutang Pajak dan Cara Penghitungan Penyisihan Piutang Pajak (telah diubah dengan PER39/PJ/2013), seperti yang disajikan pada Tabel III di bawah ini. 
Tabel 3

Kriteria Kualitas Piutang Perpajakan

\begin{tabular}{|c|c|}
\hline $\begin{array}{l}\text { Kualitas } \\
\text { Piutang }\end{array}$ & Kriteria \\
\hline Lancar & $\begin{array}{l}\text { a. Umur piutang }<4 \text { bulan dan belum diberitahukan SP; atau } \\
\text { b. Telah diterbitkan SK Persetujuan Angsuran/Penundaan Pembayaran Pajak } \\
\text { dan belum melewati batas waktu angsuran/penundaan; atau } \\
\text { c. Umur piutang pajak }<1 \text { tahun untuk Piutang PBB sektor Pertambangan } \\
\text { minyak bumi, gas bumi dan panas bumi (PBB migas dan pabum) }\end{array}$ \\
\hline $\begin{array}{l}\text { Kurang } \\
\text { Lancar }\end{array}$ & $\begin{array}{l}\text { a. Umur piutang antara } 4 \text { bulan s.d } 1 \text { tahun dan belum diterbitkan SP; atau } \\
\text { b. Telah diterbitkan SK Persetujuan Angsuran/Penundaan Pembayaran Pajak } \\
\text { tetapi telah melewati batas waktu angsuran/penundaan; atau } \\
\text { c. Telah dilaksanakan penagihan seketika dan sekaligus; atau } \\
\text { d. Telah diterbitkan SP dengan umur SP < } 1 \text { tahun; atau } \\
\text { e. Telah dilaksanakan penyitaan dengan total nilai Barang Sitaan }>25 \% \text { dari } \\
\text { total nilai piutang pajak yang menjadi dasar penyitaan, sebagaimana } \\
\text { tercantum dalam Berita Acara Pelaksanaan Sita (BAPS); atau } \\
\text { f. } \quad \text { Umur piutang pajak } 1 \text { s.d } 3 \text { tahun (PBB migas dan pabum) }\end{array}$ \\
\hline Dira & $\begin{array}{l}\text { a. Umur piutang } 1 \text { s.d } 2 \text { tahun dan belum diterbitkan SP; atau } \\
\text { b. Telah diterbitkan SP dengan umur SP } 1 \text { s.d } 2 \text { tahun; atau } \\
\text { c. Telah dilaksanakan penyitaan dengan total keseluruhan nilai Barang Sitaan } \\
\text { s.d } 25 \% \text { dari total nilai piutang pajak yang menjadi dasar penyitaan, } \\
\text { sebagaimana tercantum dalam BAPS; atau } \\
\text { d. Sedang diajukan upaya hukum (pembetulan, keberatan/banding, } \\
\text { pengurangan, penghapusan/pembatalan, gugatan/sanggahan dan peninjauan } \\
\text { kembali); atau } \\
\text { WP atau Penanggung Pajak sedang dalam proses pailit atau proses } \\
\text { e. Penundaan Kewajiban Pembayaran Utang. } \\
\text { f. Umur piutang pajak } 3 \text { s.d } 5 \text { tahun (PBB migas dan pabum) }\end{array}$ \\
\hline Macet & $\begin{array}{l}\text { a. Umur piutang }>2 \text { tahun dan belum diterbitkan SP; atau } \\
\text { b. Telah diterbitkan SP dengan umur SP > } 2 \text { tahun; atau } \\
\text { c. WP Non Efektif (NE); atau } \\
\text { d. Terhadap WP atau Penanggung Pajak sedang dilakukan proses hukum oleh } \\
\text { instansi yang berwenang (penyidikan, penyelidikan, ataupun penuntutan } \\
\text { terkait tindak pidana di bidang perpajakan atau tindak pidana lainnya) dalam } \\
\text { waktu kurang dari } 58 \text { hari hak penagihannya akan daluwarsa; atau } \\
\text { e. Hak penagihannya telah daluwarsa; atau } \\
\text { f. Hak penagihannya belum daluwarsa tetapi telah dibuatkan laporan hasil } \\
\text { penelitian (administrasi ataupun setempat) yang menyimpulkan bahwa } \\
\text { piutang pajak tersebut memenuhi syarat untuk dihapuskan. } \\
\text { g. Umur piutang pajak }>5 \text { tahun (PBB migas dan pabum) }\end{array}$ \\
\hline
\end{tabular}

Sumber: Data diolah oleh peneliti, Tahun 2020 
Berdasarkan Tabel 3, umur piutang tidak sepenuhnya menunjukkan tingkat kolektibilitas piutang (lancar, kurang lancar, diragukan dan macet) jika terdapat contoh kondisi sebagai berikut: (a) Jika sudah diterbitkan SP, piutang pajak tidak boleh dikelompokkan sebagai lancar walaupun umur piutang kurang dari satu tahun. Piutang pajak minimal harus dikategorikan kurang lancar walaupun umur kurang dari satu tahun. Begitu pula jika telah dilaksanakan penagihan seketika dan sekaligus, piutang pajak harus dikategorikan minimal kurang lancar walaupun umur piutang kurang dari satu tahun; (b) Jika dilakukan penyitaan, piutang pajak dikelompokkan minimal sebagai kurang lancar atau diragukan tanpa memperhatikan umur piutang; (c) Jika WP melakukan upaya hukum berupa keberatan, gugatan/sanggahan dan peninjauan kembali, piutang pajak dikelompokkan sebagai diragukan walaupun umur piutang kurang dari satu tahun; (d) Jika ada penyidikan, penyelidikan, ataupun penuntutan terkait tindak pidana di bidang perpajakan atau tindak pidana lainnya maka dikelompokkan menjadi diragukan walaupun umur piutang masih di bawah satu tahun; dan (e) Jika WP Orang Pribadi meninggal dunia, maka piutang pajak dikelompokkan menjadi macet walaupun umur piutang masih satu tahun.

Untuk piutang perpajakan di DJBC, umur piutang sudah menunjukkan tingkat kolektibitas karena berdasarkan Pasal 12
Peraturan Dirjen Bea dan Cukai Nomor: P -47/BC/2010 tentang Pedoman Penatausahaan Piutang di DJBC dinyatakan bahwa piutang pajak ditetapkan sebagai piutang lancar apabila umur piutang kurang dari satu tahun, piutang kurang lancar apabila umur piutang satu sampai dua tahun, piutang diragukan apabila umur piutang dua sampai tiga tahun dan piutang macet apabila umur piutang lebih dari tiga tahun.

Pengungkapan piutang menurut umur dan kolektibilitas menjadi sangat penting karena memiliki tujuan, yaitu agar pengguna LKPP dapat: (a) Mengetahui nilai loss contingency, yaitu besarnya kerugian yang mungkin akan terjadi jika pemerintah gagal melakukan tindakan penagihan pajak; (b) Mengukur potensi ekonomi yang secara rasional dapat direalisasikan atau Net Realizable Value (NRV) dari pelunasan tunggakan pajak oleh WP; (c) Mengukur kinerja penagihan pajak yang dilakukan pemerintah; dan (d) Menilai tingkat kepatuhan pembayaran tunggakan oleh WP.

\section{Kriteria 3: Pengungkapan} Penyelesaian Piutang atau Tindakan Penagihan Pajak

CaLK LKPP TA 2017 s.d 2019

tidak merinci nilai piutang perpajakan berdasarkan tahap penyelesaiannya atau tindakan penagihan pajak. Penagihan pajak adalah serangkaian tindakan agar 
penanggung pajak melunasi utang pajak dan biaya penagihan pajak dengan menegur, memperingatkan, melaksanakan penagihan seketika dan sekaligus, memberitahukan SP, mengusulkan pencegahan, melaksanakan penyitaan, melaksanakan penyanderaan, serta menjual barang yang telah disita (UU No. 19 tahun 1997 stdd UU No. 19 tahun 2000).

Seharusnya LKPP mengungkapkan klasifikasi piutang pajak berdasarkan tindakan penagihan terakhir yang dilakukan oleh pemerintah terhadap WP, misalnya berapa nilai piutang pajak yang sudah diterbitkan SP dan Surat Perintah Melakukan Penyitaan (SPMP) serta berapa banyak piutang pajak yang penunggak pajaknya yang dikenai pencegahan ataupun penyanderaan.

Ketiadaan pengungkapan mengenai rincian piutang perpajakan menurut tahap penyelesaiannya mengakibatkan pengguna LKPP tidak dapat: (a) Mengetahui proses dan tahap-tahap yang telah dilalui pemerintah dalam upaya menagih pembayaran tunggakan pajak; dan (b) mengukur kinerja penagihan piutang perpajakan yang dicapai oleh pemerintah.

\section{Kriteria 4: Pengungkapan Nilai Jaminan atau Sita Jaminan}

Hasil analisis untuk kriteria 4 ini disajikan pada Tabel 4 di bawah ini.
Tabel 4

Pengungkapan Nilai Jaminan atau Sita Jaminan

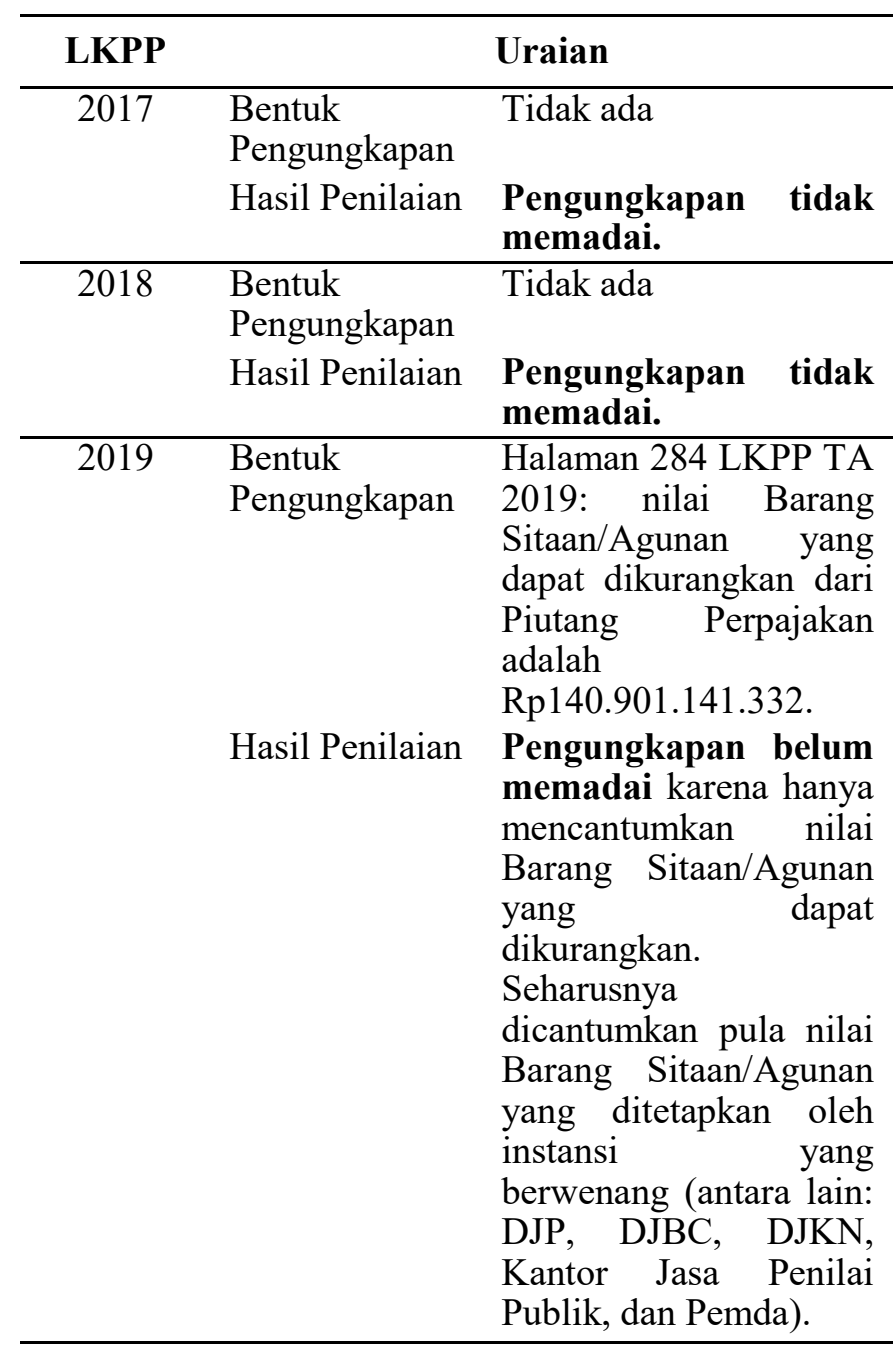

Sumber: Data diolah oleh peneliti, Tahun 2020

Berdasarkan Peraturan Dirjen Pajak nomor Per-01/PJ/2020, menurut persentase nilai barang yang dapat diperhitungkan sebagai pembentuk penyisihan piutang pajak, kelompok barang yang dapat dijadikan nilai jaminan atau sita jaminan adalah:

Diperhitungkan 100\%: surat berharga yang diterbitkan oleh Bank Indonesia, surat berharga negara, garansi bank, tabungan dan deposito yang diblokir pada bank, emas, dan/atau logam mulia; (b) 
Diperhitungkan $80 \%$ : hak tanggungan atas tanah bersertifikat hak milik (SHM) dan/ atau hak guna bangunan (SHGB) berikut bangunan di atasnya; (c) Diperhitungkan 60\%: Tanah bersertifikat SHM, SHGB, dan/atau hak pakai, berikut bangunan di atasnya yang tidak diikat dengan hak tanggungan; dan (d) Diperhitungkan 50\%: Tanah dengan bukti kepemilikan berupa Surat Girik (letter C) dan/atau bukti kepemilikan nonsertifikat lainnya yang dilampiri SPPT terakhir, hak hipotek atas pesawat udara dan/atau kapal laut dengan isi kotor paling sedikit $20 \mathrm{~m}^{3}$, jaminan fidusia atas kendaraan bermotor, serta pesawat udara, kapal laut, atau kendaraan bermotor yang tidak diikat sesuai ketentuan peraturan perundang-undangan dan disertai bukti kepemilikan.

$$
\text { Dalam Laporan Keuangan }
$$

Kementerian Keuangan TA 2017 dan 2018, nilai estimasi harga pasar aset WP yang dilakukan penyitaan yang belum dilakukan penjualan secara lelang dan atau penjualan yang dikecualikan dari lelang masingmasing sebesar Rp1,75 triliun dan Rp0,6 triliun. Seharusnya nilai jaminan/sita jaminan, beserta jenis kelompoknya, dapat diungkapkan dalam LKPP karena tidak adanya pengungkapan tersebut menyebabkan pengguna LKPP tidak dapat: (a) Mengetahui nilai dan jenis harta penunggak pajak yang berhasil disita oleh pemerintah dan dasar perhitungan penyisihan piutang pajak; (b) mengukur potensi ekonomi berupa kas yang bisa direalisasikan jika jaminan atau aset sita dijual sebagai ganti pembayaran tunggakan pajak; dan (c) Menilai upaya dan keseriusan pemerintah dalam menagih para WP yang belum menulasi kewajiban perpajakannya.

\section{Kriteria 5: Pengungkapan Perselisihan (Sengketa) Piutang Pajak}

Hasil analisis untuk kriteria 5 ini disajikan pada Tabel 5 di bawah ini.

\section{Tabel 5}

\section{Pengungkapan Perselisihan (Sengketa) Piutang Pajak}

\begin{tabular}{|c|c|c|}
\hline LKPP & & URAIAN \\
\hline \multirow[t]{8}{*}{2017} & Bentuk & Halaman 115: Nominal ketetapan pajak \\
\hline & Pengungkapan & kurang bayar yang menjadi sengketa \\
\hline & & pajak, yang belum diterbitkan keputusan \\
\hline & & atau putusan sampai dengan tanggal 31 \\
\hline & & Desember 2017 adalah Rp198,25 triliun. \\
\hline & Hasil & Pengungkapan belum memadai karena \\
\hline & Penilaian & CALK tidak memberi nilai rincian jenis \\
\hline & & $\begin{array}{l}\text { sengketa pajak, yaitu keberatan, banding, } \\
\text { gugatan dan peninjauan kembali. }\end{array}$ \\
\hline \multirow[t]{17}{*}{2018} & \multirow{17}{*}{$\begin{array}{l}\text { Bentuk } \\
\text { Pengungkapan } \\
\text { Hasil } \\
\text { Penilaian }\end{array}$} & \multirow[t]{2}{*}{ Tidak ada } \\
\hline & & \\
\hline & & \multirow{15}{*}{$\begin{array}{l}\text { Pengungkapan tidak memadai karena } \\
\text { CALK tidak mengungkapkan nilai } \\
\text { piutang pajak dalam sengketa. } \\
\text { Pada halaman } 56 \text { pada LHP BPK atas } \\
\text { LKPP } 2018 \text { (Nomor: } \\
\text { 71b/LHP/XV/05/2019 tanggal } 20 \text { Mei } \\
\text { 2019), disebutkan bahwa per tanggal } 31 \\
\text { Desember } 2018 \text { terdapat } 13 \text { ketetapan } \\
\text { pajak senilai Rp57.956.226.976 yang } \\
\text { belum dapat dicatat sebagai piutang } \\
\text { perpajakan karena masih dalam tahap } \\
\text { upaya hukum. Data Sekretariat } \\
\text { Pengadilan Pajak juga menunjukkan } \\
\text { bahwa masih terdapat 1.375 berkas } \\
\text { banding yang belum diselesaikan hingga } \\
\text { 31 Desember } 2018 \text {. }\end{array}$} \\
\hline & & \\
\hline & & \\
\hline & & \\
\hline & & \\
\hline & & \\
\hline & & \\
\hline & & \\
\hline & & \\
\hline & & \\
\hline & & \\
\hline & & \\
\hline & & \\
\hline & & \\
\hline & & \\
\hline \multirow[t]{18}{*}{2019} & Bentuk & \multirow{10}{*}{$\begin{array}{l}\text { Hal 282-283: } \\
\text { 1. Ketetapan Pajak yang belum dapat } \\
\text { diakui sebagai piutang pajak karena } \\
\text { masih dalam rentang waktu yang } \\
\text { diberikan kepada WP untuk } \\
\text { mengajukan upaya hukum keberatan } \\
\text { dan banding atas ketetapan pajak yang } \\
\text { diterbitkan oleh DJP sebanyak } 5.203 \\
\text { ketetapan pajak senilai Rp13,87 triliun } \\
\text { dan 41 ketetapan pajak senilai } \\
\text { USD113 juta: }\end{array}$} \\
\hline & Pengungkapan & \\
\hline & & \\
\hline & & \\
\hline & & \\
\hline & & \\
\hline & & \\
\hline & & \\
\hline & & \\
\hline & & \\
\hline & & \multirow{4}{*}{$\begin{array}{l}\text { 2. Ketetapan Pajak belum diakui sebagai } \\
\text { piutang pajak Tahun } 2019 \text { karena } \\
\text { masih dalam upaya hukum banding } \\
\text { sebanyak } 2.601 \text { ketetapan pajak } \\
\text { senilai Rp4,93 triliun. }\end{array}$} \\
\hline & & \\
\hline & & \\
\hline & & \\
\hline & Hasil & \multirow{4}{*}{$\begin{array}{l}\text { Pengungkapan belum memadai karena } \\
\text { CALK tidak memberi nilai rincian jenis } \\
\text { sengketa pajak, yaitu keberatan, banding, } \\
\text { gugatan dan peninjauan kembali (PK). }\end{array}$} \\
\hline & & \\
\hline & & \\
\hline & & \\
\hline
\end{tabular}

Sumber: Data diolah oleh peneliti, Tahun 2020 
Penyelesaian sengketa pajak adalah bentuk proses peradilan administrasi pajak. Keberatan merupakan peradilan administrasi tidak murni di DJP, sedangkan banding, gugatan dan peninjauan kembali merupakan peradilan administrasi murni di Pengadilan Pajak dan Mahkamah Agung.. Berdasarkan Laporan Tahunan DJP 2017 dan 2018, serta Laporan Tahunan Kementerian Keuangan 2019, diperoleh data jumlah sengketa pajak yang dicatat DJP, seperti yang disajikan pada Tabel 6 di bawah ini.

\section{Tabel 6}

Jumlah Kasus Sengketa Piutang Pajak

\begin{tabular}{llrrr}
\hline $\begin{array}{c}\text { Jenis } \\
\text { Sengketa }\end{array}$ & \multicolumn{1}{c}{$\begin{array}{c}\text { Tempat } \\
\text { Penyelesaian }\end{array}$} & $\mathbf{2 0 1 7}$ & $\mathbf{2 0 1 8}$ & $\mathbf{2 0 1 9}$ \\
\hline Keberatan & DJP & 9.335 & 12.418 & - \\
Banding & Pengadilan Pajak & 4.198 & 7.772 & 10.346 \\
Gugatan & Pengadilan Pajak & 1.335 & 1.885 & 2.028 \\
PK & Mahkamah Agung & 3.748 & 4.288 & 4.400 \\
Ket “_“" : Tidak ada data & & & \\
\hline
\end{tabular}

Sumber: Data diolah oleh peneliti, Tahun 2020

Tabel 6 menunjukkan banyaknya sengketa pajak yang dapat mempengaruhi NRV piutang pajak karena jika WP menang maka nilai piutang pajak pada neraca LKPP harus dikurangi. Data ini menjadi signifikan diungkapkan ke pengguna LKPP karena tingkat kemenangan pemerintah di Pengadilan Pajak hanya sebesar hanya 40,54\% pada tahun 2019 dan 43,54\% pada tahun 2018.

Tidak adanya pengungkapan nilai sengketa pajak per jenis sengketanya menyebabkan pengguna LKPP tidak dapat: (a) Mengukur loss contigency atas piutang pajak yang akan dihapuskan jika permohonan WP dikabulkan dalam proses sengketa pajak; dan (b) Menilai kinerja pemeriksaan pajak dan penanganan sengketa pajak yang dilakukan oleh pemerintah.

\section{Kriteria 6: Pengungkapan Piutang Daluarsa}

Hasil analisis untuk kriteria 6 ini disajikan pada Tabel 7 di bawah ini.

Tabel 7

Pengungkapan Piutang Pajak Daluarsa

\begin{tabular}{|c|c|c|}
\hline LKPP & & URAIAN \\
\hline \multirow[t]{2}{*}{2017} & $\begin{array}{l}\text { Bentuk } \\
\text { Pengungkapan }\end{array}$ & $\begin{array}{l}\text { Lampiram 8D: } \\
\text { Piutang pajak daluarsa sebesar Rp } 32,75 \\
\text { triliun dengan rincian per jenis pajak, } \\
\text { yaitu: (a) PPh Non Migas: Rp10,77 } \\
\text { triliun, (b) PPN: Rp4,56 triliun, (c) } \\
\text { PPnBM: Rp 55,16 miliar, (d) PBB dan } \\
\text { BPHTB: Rp4,93 miliar, dan (e) } \\
\text { Lainnya: Rp12,42 triliun. }\end{array}$ \\
\hline & Hasil Penilaian & $\begin{array}{l}\text { Pengungkapan belum memadai } \\
\text { karena hanya diungkapkan piutang } \\
\text { daluarsa di DJP, sedangkan di DJBC } \\
\text { tidak diungkapkan. }\end{array}$ \\
\hline \multirow[t]{2}{*}{2018} & $\begin{array}{l}\text { Bentuk } \\
\text { Pengungkapan }\end{array}$ & Tidak ada \\
\hline & Hasil Penilaian & $\begin{array}{l}\text { Pengungkapan tidak memadai karena } \\
\text { tidak mengungkapkan adanya nilai } \\
\text { piutang pajak daluarsa. Padahal menurut } \\
\text { berita dari situs surabaya.bisnis.com } \\
\text { diperoleh informasi bahwa: terdapat } \\
\text { penambahan piutang daluarsa sebanyak } \\
\text { Rp2,1 triliun selama TA 2018. Isi berita } \\
\text { tersebut selengkapnya sebagai berikut: } \\
\text { "Data DJP per semester 1/2018 } \\
\text { mengungkapkan jumlah piutang pajak } \\
\text { yang belum tertagih mencapai Rp106,7 } \\
\text { triliun atau naik hampir Rp19,7 triliun } \\
\text { dibandingkan dengan posisi akhir } \\
\text { Desember 2017 senilai Rp87 triliun. } \\
\text { Dari jumlah tersebut, piutang pajak yang } \\
\text { belum masuk daluwarsa senilai Rp71,8 } \\
\text { triliun atau naik sebesar Rp17,6 triliun } \\
\text { dari posisi akhir tahun lalu senilai } \\
\text { Rp54,2 triliun. Kenaikan piutang pajak } \\
\text { praktis menambah piutang pajak yang } \\
\text { masuk masa daluwarsa, jika Desember } \\
\text { tahun lalu jumlah piutang pajak } \\
\text { daluwarsa tercatat Rp32,8 triliun, } \\
\text { jumlah ini bertambah menjadi Rp34,9 } \\
\text { triliun pada akhir Juni } 2018 \text { ". }\end{array}$ \\
\hline \multirow[t]{2}{*}{2019} & $\begin{array}{l}\text { Bentuk } \\
\text { Pengungkapan }\end{array}$ & $\begin{array}{l}\text { Lampiran 8D: penambahan piutang } \\
\text { pajak daluarsa per } 31 \text { Desember } 2019 \\
\text { adalah Rp4,87 triliun. }\end{array}$ \\
\hline & Hasil Penilaian & $\begin{array}{l}\text { Pengungkapan belum memadai } \\
\text { karena hanya mengungkapkan piutang } \\
\text { daluarsa di DJP, sedangkan di DJBC } \\
\text { tidak ada. }\end{array}$ \\
\hline
\end{tabular}

Sumber: Data diolah oleh peneliti, Tahun 2020 
Piutang pajak yang telah daluwarsa tidak memiliki hak tagih sehingga tidak memenuhi kriteria sebagai aset dan harus dikeluarkan dari daftar piutang pajak. Hilangnya hak tagih tentu saja berarti suatu kerugian finansial bagi negara. Hingga 31 Desember 2019, nilai piutang daluarsa mencapai Rp39,72 triliun atau 39,72\% dari nilai Piutang Pajak pada Neraca (Rp94,69 triliun). Suatu persentase yang cukup tinggi dan memberikan gambaran rendahnya kepatuhan WP.

Ketidaklengkapan pengungkapan piutang daluarsa menyebabkan pengguna LKPP tidak dapat: (a) Mengukur nilai kerugian yang terjadi; (b) Mengukur kinerja penagihan pajak yang dilakukan pemerintah; (c) Merumuskan strategi penyuluhan pajak kepada WP untuk meningkatkan kesadaran membayar pajak; dan (d) Merumuskan strategi penagihan pajak yang benar untuk meningkatkan penerimaan pajak dan mengurangi secara signifikan nilai daluarsa piutang pajak setiap tahun.

\section{Kriteria 6: Pengungkapan Penghapusan} Piutang

Untuk $\begin{gathered}\text { memenuhi } \\ \text { lengkap, }\end{gathered}$ dasar
pengungkapan
pertimbangan penghapusan piutang pajak
di DJP dan DJBC dapat diambil pada:
a. PMK Nomor: 68/PMK.03/2012
tentang Tata Cara Penghapusan
Piutang Pajak dan Penetapan
Besarnya Penghapusan pasal 1: (1)
WP dan/atau Penanggung Pajak

meninggal dunia dan tidak mempunyai harta warisan atau kekayaan (WP Orang Pribadi); (2) WP bubar, likuidasi, atau pailit (WP Badan); (3) WP dan/atau Penanggung Pajak tidak dapat ditemukan; (4) Hak untuk melakukan penagihan pajak sudah daluwarsa; (5) Dokumen sebagai dasar penagihan pajak tidak ditemukan dan telah dilakukan penelusuran secara optimal sesuai dengan ketentuan perundangundangan di bidang perpajakan; dan (6) Hak negara untuk melakukan penagihan pajak tidak dapat dilaksanakan karena kondisi tertentu sehubungan dengan adanya perubahan kebijakan dan/atau berdasarkan pertimbangan yang ditetapkan oleh Menteri Keuangan.

b. PMK Nomor: 71/PMK.04/2012 tentang Tata Cara Penghapusan dan Penetapan Besarnya Penghapusan Piutang Bea Masuk dan/atau Cukai pasal 3: (1) Penanggung Piutang Bea Masuk dan/atau Cukai telah meninggal dunia dan tidak mempunyai harta warisan atau kekayaan; (2) Penanggung Piutang Bea Masuk dan/atau Cukai tidak dapat ditemukan; (3) Badan hukum yang bertanggung jawab terhadap Piutang Pajak Bea Masuk dan/atau Cukai, telah bubar, dilikuidasi, pailit, atau tidak dapat ditemukan; 
(d) Hak untuk melakukan penagihan bea masuk dan/atau cukai sudah kadaluwarsa; (e) Dokumen sebagai dasar penagihan bea masuk dan/atau cukai tidak ditemukan dan telah dilakukan penelusuran secara optimal sesuai dengan ketentuan perundangundangan di bidang kepabeanan dan cukai; atau (f) Hak negara untuk melakukan penagihan bea masuk dan/ atau cukai tidak dapat dilaksanakan karena kondisi tertentu sehubungan dengan adanya perubahan kebijakan dan/atau berdasarkan pertimbangan yang ditetapkan oleh Menteri.

Berdasarkan 2 (dua) PMK ini, dalam CaLK nilai piutang pajak yang dihapusbukukan seharusnya dapat disajikan menurut dasar pertimbangan, yaitu: penanggung piutang meninggal dan tidak mempunyai harta warisan, WP Badan bubar/likuidasi, penanggung piutang tidak dapat ditemukan, daluwarsa penagihan, dokumen sebagai dasar penagihan pajak tidak ditemukan karena hilang/rusak, dan perubahan kebijakan.

Ketidaklengkapan pengungkapan atas penghapusbukuan adalah menyebabkan pengguna LKPP tidak dapat: (a) Mengetahui gambaran objektif tentang kemampuan negara dalam menghasilkan penerimaan negara; (b) Mengetahui daftar WP yang dihapuskan tunggakan pajaknya; dan (c) Mengetahui penyebab dan alasan penghapusan piutang pajak dalam rangka merumuskan kebijakan atau aturan baru di bidang perpajakan untuk mengurangi secara signifikan pada tahun-tahun selanjutnya nilai piutang yang dihapus dari neraca.

Hasil analisis untuk kriteria 7 ini disajikan pada Tabel 8 .

Tabel 8

Pengungkapan Penghapusan Piutang

\begin{tabular}{|c|c|c|}
\hline LKPP & & URAIAN \\
\hline 2017 & $\begin{array}{l}\text { Bentuk } \\
\text { Pengungkapan }\end{array}$ & 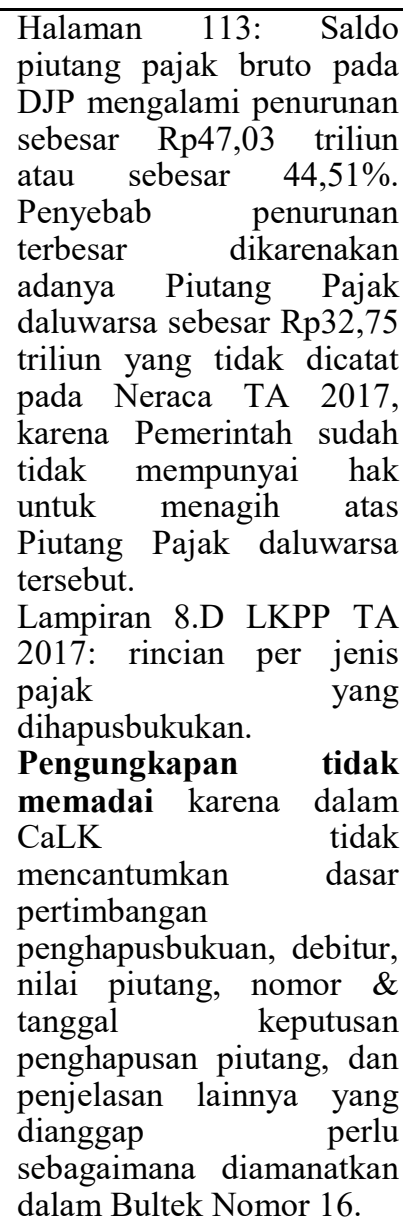 \\
\hline $\begin{array}{c}2018 \\
\& \\
2019\end{array}$ & $\begin{array}{l}\text { Bentuk } \\
\text { Pengungkapan } \\
\text { Hasil Penilaian }\end{array}$ & $\begin{array}{lr}\text { Pengungkapan } & \text { tidak } \\
\text { memadai karena } & \text { dalam } \\
\text { CALK } & \text { tidak } \\
\text { mencantumkan } & \text { dasar } \\
\text { pertimbangan } & \\
\text { penghapusbukuan } & \text { dan } \\
\text { piutang pajak } & \text { yang } \\
\text { dihapusbukukan } & \text { pada } \\
\text { tahun 2018 dan 2019. }\end{array}$ \\
\hline
\end{tabular}

Sumber: Data diolah oleh peneliti, Tahun 2020 


\section{Kriteria 8: Pengungkapan Piutang Ekstrakomptabel}

Hasil analisis untuk kriteria 8 ini disajikan pada Tabel 9.

Tabel 9

Pengungkapan Piutang Ekstrakomptabel

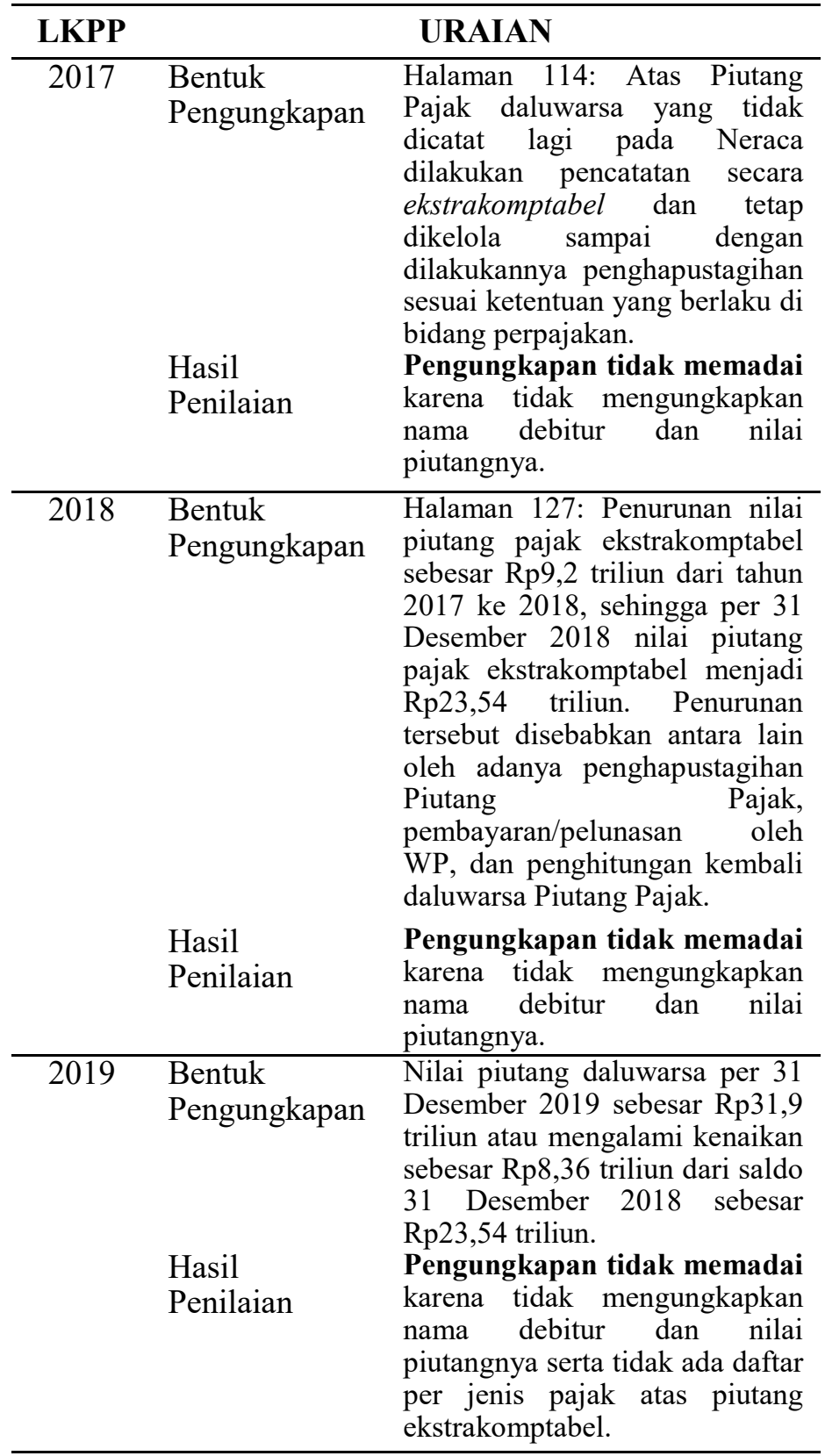

Sumber: Data diolah oleh peneliti, Tahun 2020

Karena jumlahnya penunggak pajak sangat banyak, pemerintah dapat melakukan seleksi dengan menggunakan parameter nilai tertentu untuk pengungkapan informasi dalam LKPP, misalnya tunggakan pajak di atas $\mathrm{Rp} 1$ miliar, atau 100 penunggak terbesar. Contoh pengungkapan dapat dilihat pada situs Departement of Taxation and Finance of New York State yang mengumumkan masing-masing 250 penunggak pajak korporasi dan individu setiap bulan.

Selain itu, LKPP TA 2017 s.d 2018 tidak mencantumkan judul yang tegas terkait pengungkapan piutang ekstrakomptabel. Lampiran yang ada diberi judul "piutang daluarsa per tanggal 31 Desember 20xx". Hal ini menjadi kurang tepat karena piutang ekstrakomptabel tidak sepenuhnya sama dengan piutang daluarsa. Piutang ekstrakomptabel adalah gunggungan dari piutang yang dihapusbukukan yang masih harus diadministrasikan oleh pemerintah. Adapun piutang yang dihapusbukukan tidak hanya berasal dari piutang daluarsa tapi dapat berasal dari piutang yang penanggung pajaknya meninggal atau piutang yang dokumen penagihannya hilang, sebagaimana disebutkan dalam PMK Nomor: 68/PMK. 03/2012 dan PMK Nomor: 71/PMK.04/2012.

Ketidaklengkapan pengungkapan atas daftar ekstrakomptabel menyebabkan pengguna LKPP tidak dapat: Mengetahui nilai piutang ekstrakomptabel yang harus tetap diadministrasikan dengan baik sampai dengan dilakukannya penghapustagihan sesuai ketentuan yang 
Dari Tabel 11, dapat terlihat bahwa prinsip pengungkapan lengkap belum diterapkan dengan baik dalam kurun waktu 3 tahun. Sedikitnya kriteria yang dipenuhi menunjukkan tidak adanya perbaikan signifikan dalam penerapan prinsip pengungkapan lengkap. Bahkan pengungkapan informasi piutang perpajakan dalam LKPP TA 2017 lebih baik dari LKPP TA 2018. Hingga tahun 2019, hanya ada 1 kriteria yang pengungkapannya memadai (kriteria nomor 2), empat kriteria yang pengungkapannya belum memadai karena masih membutuhkan tambahan informasi dari pengungkapan yang sudah ada (nomor 1, 4, 5 dan 6), serta empat kriteria tidak memadai karena tidak menyajikan informasi yang dipersyaratkan (kriteria 3, 7, 8 dan 9).

Secara umum, terdapat ketidaklengkapan 7 jenis informasi yang berkontribusi pada rendahnya pemenuhan Prinsip Pengungkapan Lengkap LKPP TA 2017 s.d 2019, yaitu: (1) Kebijakan Akuntansi terkait penambahan dan pengurangan piutang perpajakan, baik piutang pajak di DJP maupun di DJBC; (2) Rincian saldo piutang menurut status penyelesaian piutang, yaitu nilai piutang yang sudah diterbitkan ST, SP, SPMP, BAPS, Pemblokiran, Pencegahan dan Penyanderaan; (3) Jenis dan nilai jaminan atau sita jaminan; (4) Rincian saldo piutang yang masih dalam proses sengketa di tingkat keberatan, banding, dan peninjauan kembali; (5) Nilai piutang pajak yang daluarsa di DJBC (bea masuk, cukai dan PPh 22 Impor); (6) Nilai dan jenis rincian piutang pajak ekstrakomptable; dan (7) Alasan/pertimbangan penghapusbukuan pajak, serta nama debitur dan nilai pajak yang dihapusbukukan dan dihapustagihkan.

\section{KESIMPULAN DAN SARAN \\ Kesimpulan}

CaLK bukan keterangan pelengkap yang sifatnya sukarela bagi sebuah Laporan Keuangan tetapi wajib karena memberi makna pada angka-angka pada face LKPP, serta membantu pengguna LKPP untuk memahami isi LKPP dan menilai kinerja keuangan pemerintah. Berdasarkan hasil penilaian terhadap penerapan prinsip pengungkapan lengkap dengan menggunakan 9 kriteria, dapat disimpulkan bahwa: (1) LKPP TA 2017 s.d 2018 belum memenuhi prinsip pengungkapan lengkap atas akun piutang perpajakan karena tidak ada kriteria penilaian yang dipenuhi. Adapun LKPP TA 2019, walaupun juga belum memenuhi prinsip pengungkapan lengkap, namun lebih baik dari dua tahun sebelumnya, karena ada satu kriteria penilaian yang dipenuhi; dan (2) Tidak ada peningkatan yang berarti dalam penerapan prinsip pengungkapan lengkap atas piutang perpajakan dalam LKPP pada kurun waktu 3 tahun (2017 s.d 2019).

\section{Saran}

Untuk meningkatkan kualitas penerapan prinsip pengungkapan lengkap pada LKPP 2020 dan LKPP tahun-tahun selanjutnya, penulis memberikan saran kepada pihak-pihak yang terlibat dalam proses penyusunan dan pertanggungjawaban LKPP, sebagai berikut: (1) Bagi Kementerian Keuangan, diharapkan dapat membuat pedoman penyusunan CaLK untuk LKPP agar dapat dijadikan acuan yang lebih detail untuk mengungkapkan informasi terkait akun-akun yang disajikan dalam LKPP 
khususnya akun piutang perpajakan, mengungkapkan informasi dalam LKPP: kenaikan/penurunan piutang pajak, nilai piutang pajak berdasarkan tindakan penagihan terakhir yang dilaksanakan kepada WP/penanggung pajak, nilai jaminan atau sita jaminan, nilai piutang pajak berdasarkan upaya hukum yang sedang dilakukan, penyebab terjadinya piutang pajak daluarsa, serta nama debitur dan nilai piutang secara selektif terkait penghapusbukuan piutang pajak, piutang ekstrakomptabel dan penghapustagihan piutang pajak, memperhatikan standar akuntansi pemerintahan, beserta buletin teknisnya, dan peraturan terkait dalam pengungkapan informasi piutang perpajakan di LKPP, dan memberikan pelatihan teknis mengenai implementasi prinsip pengungkapan lengkap yang dimuat dalam SAP dan Bultek SAP kepada unit yang menyusun LKPP; (2) Bagi BPKP, diharapkan dapat memasukkan penerapan prinsip pengungkapan lengkap sebagai area yang harus direviu dalam program kerja reviu LKPP, dan menggunakan Bultek SAP dan peraturan terkait dalam melakukan reviu tersebut; (3) Bagi BPK, diharapkan dapat memasukkan penerapan prinsip pengungkapan lengkap sebagai area yang harus diaudit dalam program kerja audit LKPP, dan menggunakan Bultek SAP dan peraturan terkait untuk melakukan audit tersebut; dan (4) Bagi DPR, diharapkan dapat mendorong pemerintah menyediakan informasi yang lebih lengkap terkait piutang perpajakan dan kemudian melakukan analisis terhadap informasi yang disajikan dalam LKPP untuk menilai kinerja pemerintah.

\section{DAFTAR PUSTAKA}

Arif, Bahtiar, Muhlis dan Iskandar. (2002). Akuntansi Pemerintahan. Jakarta: Penerbit Salemba Empat.

CNN Indonesia. DPR Minta Sri Mulyani Kejar Piutang daripada Tarik Utang. Diakses dari www.cnnindonesia.com/ ekonomi/20200826152610-532-539577/ pada tanggal 8 September 2020.

Detik Finance. Pengumuman Penunggak Pajak Jangan Ganggu Iklim Usaha. Diakses dari finance.detik.com/berita-ekonomibisnis/d-1288943 pada tanggal 9 September 2020.

Departement of Taxation and Finance of New York State. New York State Delinquent Taxpayers. Diakses dari www.tax.ny.gov/enforcement/nysdelinquent-taxpayers.htm pada tanggal 6 September 2020.

Kurniati, D. Saldo Piutang Pajak Terus Meningkat, DPR Minta DJP Lakukan Ini. Diakses dari news.ddtc.co.id/ pada tanggal 8 September 2020.

Direktorat Jenderal Pajak. (2013). Undangundang KUP dan Peraturan Pelaksanaannya. Jakarta: Direktorat Penyuluhan, Pelayanan, dan Hubungan Masyarakat.

(2017). Laporan

Tahunan. Jakarta: Sekretariat DJP.

(2018). Laporan Tahunan. Jakarta: Sekretariat DJP.

Martani, Dwi, dkk. (2012). Akuntansi Keuangan Menengah Berbasis PSAK. Jakarta: Penerbit Salemba Empat. 
Haryadi, Eko Susilo dkk. (2015). Analisis Pengungkapan (Disclosure) Laporan Keuangan Kabupaten yang Meraih Opini Audit Wajar Tanpa Pengecualian (WTP) Dua Tahun Berturut-Turut. Jurnal Akuntansi, Vol.3, No.2, April 2015:184195.

Governmental Accounting Standards Board. (1999). Statement No. 34 of the Governmental Accounting Standards Board. USA.

Hilmi, Amiruddin Zul dan Dwi Martani. (2012). Analisis Faktor-Faktor Yang Mempengaruhi Tingkat Pengungkapan Laporan Keuangan Pemerintah Provinsi. Simposium Nasional Akuntansi XV.

Ingram, Robert W. (1984). Economic Incentives and the Choice of State Government Accounting Practices. Journal of Accounting Research, vol. 22, no. 1, 1984, pp. 126-144.

Kieso, Donald dan Jerry Weigandt. (2008). Akuntansi Intermediate (Edisi 12). Terjemahan oleh Emil Salim. Jakarta: Gloria Aksara Pratama.

Mahmudi. (2018). Akuntansi Sektor Publik. Yogyakarta: UII Press:.

Mardiasmo. (2018). Akuntansi Sektor Publik. Yogyakarta: Penerbit Andi.

Ministry of Finance of Republic of China. Major Taxpayers In Arrears To Be Announced. Diakses dari mof.gov.tw/Eng/singlehtml/ f48d641f159a4866b1d31c0916fbcc71? cntId=edot58240 pada tanggal 6 September 2020.

Mursyidi. (2013). Akuntansi Pemerintahan di Indonesia. Bandung: Refika Aditama.

Rachmat. (2011). Akuntansi Pemerintahan. Bandung: Pustaka Setia:.

Republik Indonesia. (1995). Undang-Undang Nomor 10 Tahun 1995 tentang Kepabeanan std Undang-Undang Nomor 17 Tahun 2006. Sekretariat Negara. Jakarta.
. (1995). Undang-Undang Nomor 11 Tahun 1995 tentang Cukai std Undang-Undang Nomor 39 Tahun 2007. Sekretariat Negara. Jakarta.

(2010). Peraturan Pemerintah Nomor 71 Tahun 2010 tentang Standar Akuntansi Pemerintahan. Pemerintah Indonesia. Jakarta.

(2018). Laporan Keuangan Pemerintah Pusat TA 2017. Jakarta: Kementerian Keuangan.

(2019). Laporan

Keuangan Pemerintah Pusat TA 2018 dan Laporan Hasil Pemeriksaan oleh BPK atas LKPP TA 2018. Jakarta: Kementerian Keuangan.

(2020). Laporan Keuangan Pemerintah Pusat TA 2018 dan Laporan Hasil Pemeriksaan oleh BPK atas LKPP TA 2019. Jakarta: Kementerian Keuangan.

Kementerian Keuangan. (2002). Keputusan Menteri Keuangan Nomor 302/ KMK.01/2002 tentang Pemberian Pertimbangan Atas Usul Penghapusan Piutang Negara yang Berasal dari Instansi Pemerintah atau Lembaga Negara. Kementerian Keuangan. Jakarta.

(2009). Peraturan Direktur Jenderal Pajak Nomor 08/ PJ/2009 tentang Pedoman Akuntansi Piutang Pajak. Direktorat Jenderal Pajak. Jakarta.

(2010). Peraturan Direktur Jenderal Bea dan Cukai Nomor P-47/BC/2010 tentang Pedoman Penatausahaan Piutang di Direktorat Jenderal Bea Dan Cukai. Direktorat Jenderal Bea dan Cukai. Jakarta.

(2012). Peraturan Menteri Keuangan Nomor: 68/PMK.03/2012 tentang Tata Cara Penghapusan Piutang Pajak dan Penetapan Besarnya 
Penghapusan. Kementerian Keuangan. Jakarta.

. (2012). Peraturan Menteri Keuangan Nomor: 71/PMK.04/2012 tentang Tata Cara Penghapusan dan Penetapan Besarnya Penghapusan Piutang Bea Masuk dan/atau Cukai. Kementerian Keuangan. Jakarta.

. (2012). Peraturan Direktur Jenderal Pajak Nomor: PER-02/PJ/2012 tentang Penggolongan Kualitas Piutang Pajak dan Cara Penghitungan Penyisihan Piutang Pajak. Direktorat Jenderal Pajak. Jakarta.

. (2018). Peraturan Menteri Keuangan Nomor 43/PMK.03/2018 tentang Kebijakan Akuntansi Penghapusbukuan Piutang Pajak yang Telah Daluwarsa. Kementerian Keuangan. Jakarta.

Komite Standar Akuntansi Pemerintahan. (2014). Buletin Teknis Standar Akuntansi Pemerintahan Nomor 16 tentang Akuntansi Piutang Berbasis Akrual. Jakarta: KSAP.

Sabeni, Arifin dan Imam Ghozali. (2008). PokokPokok Akuntansi Pemerintahan. Yogyakarta: BPFE-Yogyakarta.

Sekretariat Pengadilan Pajak. (2019). Penyelesaian Sengketa Pajak Tahun 2013 -2018 dan Jumlah Berkas Masuk 20132018. Diakses dari www.setpp.kemenkeu.go.id/statistik pada tanggal 5 Agustus 2019.

Sujarweni, V. Wiratna. (2015). Akuntansi Sektor Publik: Teori Konsep Aplikasi. Yogyakarta: Penerbit Pustaka Baru Press.

Suwiknyo, Edi. Piutang Tak Tertagih Menggunung. Diakses dari www.surabaya.bisnis.com/read/20180910 /433/836661/penerimaan-pajak-piutangtak-tertagih-menggunung pada tanggal 5 Agustus 2019. 